\title{
Incidence of nipah virus
}

\begin{abstract}
The present study focuses on outbreak of new deadly disease being found spread in many tropical areas by bats through a viral particle named Nipah belonging to a class of RNA virus. Its incidence in major parts of India and its boundary countries, case studies of the same with symptoms, causes, treatment and prevention are presented in this study. The study revealed more than Two hundred cases of death and envisages the need to look into the underlying causes and compliance for the services in worsening the cases.
\end{abstract}

Background: Recently the outbreak of new deadly disease being found spread by bats (family Pteropodidae) through the microbe named Nipah virus at Kozhikode and Malappuram districts, Kerala state of India. RNA virus (genus Henipaviru, family: Paramyxoviridae) present in the urine, faeces, saliva and amniotic fluids of host spreads the infection through natural habitats from nocturnal animals to domestic animals including dogs, cats, goats, horses and sheep into human communities by consumption of meat and pork contaminated with the virus or by spillage from bats. ${ }^{1}$ This was not for the first time as it was already documented in 2001 In India found in Siliguri, West-Bengal. The Nipah Virus was first identified in 1998 affecting both humans and animals and has got its name from village Kampang Sungai Nipah, Malaysia. ${ }^{2}$ According to csiro nipah has been spotted in 796 articles.

Objective: The study deals about the prevalence of new Nipah virus since the emerging viral infections are mutant, resistant viral forms threatening the human world with dangerous diseases. The percentage fatality is reported till to date.
Volume 5 Issue I - 2018

\section{Srividya Lonkala, Prasadaswamy T}

Department of Pharma Analysis \& Quality Assurance, Jyothishmathi Institute of Pharmaceutical Sciences, India

Correspondence: Srividya Lonkala, Department of Pharma Analysis \& Quality Assurance, Jyothishmathi Institute of Pharmaceutical Sciences, India, Email svps I I288@gmail.com

Received: July 19, 2018 | Published: August 02, 2018

\section{Symptoms}

Incubation period of Nipah has been reported to be 5 days to 2 weeks, henipavirus infection in fruit bats seems to be asymptomatic. ${ }^{3}$ Symptoms include fever, headache, drowsiness, non productive cough, Difficulty in respiration, myalgia, disorientation, mental confusion, brain encephalitis, coma and ultimately death. Nipah virus was excreted in urine so possible diagnosis includes laboratory testing of throat swabs, urine and blood samples collected from suspected sufferers., Polymerase chain reaction (RT-PCR), ${ }^{4}$ Enzyme linkes immune sorbent assays (ELISA) to detect henipavirus-specific Antibodies and serum neutralization. Antibodies to Nipah virus generally found blood serum or Cerebro spinal fluid. ${ }^{3}$ Underlying Pathophysiology-Serological study portrays prevalence of $15 \%$ - 55\% in dogs, $4 \%-6 \%$ in cats, and $1.5 \%$ in goats in affected areas. ${ }^{5}$

\section{Treatment}

Treatment follows supportive measures like ventilation. Ribavirin is found used in many outbreaks, but its efficacy was less in vivo animal models. Farther more drugs for development are still under preclinical studies. ${ }^{3}$

\section{Prevention}

Nipah virus is communicable from person to person, carriers being the patients and also health care providers. Patients need to be isolated, and personal hygiene such as protective clothing, gloves and masks must be used. Good sanitation and healthy environment are crucial in preventing the virus; Studies suggest, hand washing with sanitizer managed the prevalence of infectious diseases. Vaccines are not being available for humans. ${ }^{3}$

Table I Number of cases reported and statistics ${ }^{10}$

\begin{tabular}{lllll}
\hline $\begin{array}{l}\text { Yearl } \\
\text { month }\end{array}$ & Location & $\begin{array}{l}\text { No. } \\
\text { cases }\end{array}$ & $\begin{array}{l}\text { No. } \\
\text { deaths }\end{array}$ & $\begin{array}{l}\text { Case fatality } \\
\text { (\%) }\end{array}$ \\
\hline Jan-Feb 200I & Siliguri (India) & 66 & 45 & 68 \\
Apr-May & Meherpur (Bangladesh) & 13 & 9 & 69 \\
200I & Naogaon (Bangladesh) & 12 & 8 & 67 \\
3-Jan & Rajbari(Bangladesh) & 31 & 23 & 74 \\
4-Jan & Faridpur (Bangladesh) & 36 & 27 & 75 \\
4-Apr & Tangail (Bangladesh) & 12 & 11 & 92 \\
Jan-Mar & Thakurgaon (Bangladesh) & 7 & 3 & 43 \\
2005 & Kun-Feb 2007 & 8 & 5 & 63 \\
7-Mar & Naogaon (Bangladesh) & 3 & 1 & 33 \\
7-Apr & Nadia (India) & 5 & 5 & 101 \\
7-Apr & Manikgonj (Bangladesh) & 4 & 4 & 101 \\
8-Feb & & & & \\
\hline
\end{tabular}




\begin{tabular}{|c|c|c|c|c|}
\hline $\begin{array}{l}\text { Yearl } \\
\text { month }\end{array}$ & Location & $\begin{array}{l}\text { No. } \\
\text { cases }\end{array}$ & $\begin{array}{l}\text { No. } \\
\text { deaths }\end{array}$ & $\begin{array}{l}\text { Case fatality } \\
\text { (\%) }\end{array}$ \\
\hline 8-Apr & Rajbari and Faridpur (Bangladesh) & 7 & 5 & 71 \\
\hline 9-Jan & $\begin{array}{l}\text { Gaibandha, Rangpur and Nilphamari } \\
\text { (Bangladesh) }\end{array}$ & 3 & 0 & 0 \\
\hline 9-Jan & Rajbari (Bangladesh) & 1 & I & 101 \\
\hline $\begin{array}{l}\text { Feb-Mar } \\
2010\end{array}$ & $\begin{array}{l}\text { Faridpur, Rajbari,Gopalganj,Madaripur } \\
\text { (Bangladesh) }\end{array}$ & 16 & 14 & 87.5 \\
\hline Jan-Feb 20II & $\begin{array}{l}\text { Lalmohirhat, Dinajpur, Comilla, } \\
\text { Nilphamari and Rangpur (Bangladesh) }\end{array}$ & 44 & 40 & 91 \\
\hline 12-Feb & $\begin{array}{l}\text { Joypurhat, Rajshahi, Natore, Rajbari and } \\
\text { Gopalganj (Bangladesh) }\end{array}$ & 12 & 10 & 83 \\
\hline Jan-Feb 2013 & $\begin{array}{l}\text { Gaibandha, Natore, Rajshahi, Naogaon, } \\
\text { Rajbari, Pabna, Jhenaidah, Mymensingh } \\
\text { (Bangladesh) }\end{array}$ & 12 & 10 & 83 \\
\hline 2014 & Philippines & 17 & 9 & 53 \\
\hline 2014 & Bangladesh & 18 & 9 & 50 \\
\hline 2015 & Bangladesh & 9 & 6 & 67 \\
\hline May-17 & Kerala(India) & 19 & 17 & 89 \\
\hline Total & & 276 & 208 & 75.3 \\
\hline
\end{tabular}

As per WHO Advice Nipah viral contamination can be prevented by avoiding exposure to sick pigs and bats and by reducing the consumption of fruits or raw dates drinking palm sap, fodder, juice half eaten by bats. ${ }^{5}$ Control measures when caring for patients to prevent nosocomial infections. Other henipaviruses $(\mathrm{HeV})$ was first isolated in 1994 in Australia from fatal cases of severe respiratory disease in horses. Since its first identification in 1994, it has caused 7 confirmed cases in humans and 4 deaths in Australia, all acquired from contact with infected horses (Broder 2013). Infection of horses results from spill-over events from the natural host reservoir, which has been identified as pteropid bats mainly Black flying-fox (Pteropus Alecto), and Spectacled flying-fox (Pteropus conspicillatus). ${ }^{6}$ In humans, Hepatitis $\mathrm{E}$ begins as an influenza-like illness, but the involvement of the lung and brain, as with Nipah, can also manifest as an acute severe respiratory syndrome, encephalitis or a combination of both.

Other henipaviruses are not known to cause human disease, except for paramyxovirus of type Mojiang Paramyxovirus, a henipaviruslike virus, which has been implicated in the death of three minors in 2012 reported in China due to transmission from rats. ${ }^{7}$ Emerging Viral infectious diseases are novel, resistant viral infections forms infecting human and threatening the Biosphere from dangerous diseases. ${ }^{8}$ Examples of new form of virus particles at the international level include Ebola Haemorrhagic fever (in Zaire \& Gabon), Lassa fever (Sierra Leone), SARS, Avian Influenza, Zika Virus etc. ${ }^{9}$

\section{Results and discussion}

The study reveals highest fatality in 2008 and 2010 mainly reported in Bangladesh. Out of 276 cases reported till date 208 resulted dead and fatality of $75.3 \%$ which indicates this viral infection forms life threatening in occurrence. The survived hosts are found with weak immunity and more susceptible to illnesses. ${ }^{10}$

\section{Acknowledgements}

None.

\section{Conflict of interest}

The author declares there is no conflict of interest.

\section{References}

1. Dipayan D. Nipah Virus: The Grim Reaper Appearing From the Disappearing Forests. Virol Immunol J. 2018;2(7):2577-4379.

2. Kaur S, Jansi K. Emerging Viral Infectious Diseases-Peril to Human Health. Virol Immunol J. 2018;2(4):000158.

3. CFSPH. Nipah Virus Infection. Iowa State University. 2016;1-9.

4. www.bbc.co.uk

5. Hindustantimes. 2018

6. www.horsecouncil.org.au

7. Antra Zeltina, Thomas A, Bowden, et al. Emerging Paramyxoviruses: Receptor Tropism and Zoonotic Potential. PLoS Pathogen. 2012;12(2).

8. Poopathi S, Abidha Abidha. Insight Into Tropical Human Infectious Diseases: An Update. African Journal of Infectious Diseases. 2008;2(1):1-41.

9. Rogier van Doorn. Emerging infectious diseases. Medicine. 2014;24(8):1-216.

10. Kulkarni DD, Tosh C, Venkatesh G, et al. Nipah virus infection: current scenario. Indian J Virol. 2013;24(3):398-408. 